\title{
Effects of proteome rebalancing and sulfur nutrition on the accumulation of methionine rich $\delta$-zein in transgenic soybeans
}

\author{
Won-Seok Kim ${ }^{1}$, Joseph M. Jez ${ }^{2}$ and Hari B. Krishnan ${ }^{1 *}$ \\ ${ }^{1}$ Plant Genetics Research Unit, Agricultural Research Service, U.S. Department of Agriculture, University of Missouri, Columbia, MO, USA \\ 2 Department of Biology, Washington University, St. Louis, MO, USA
}

Edited by:

Stanislav Kopriva, University of

Cologne, Germany

Reviewed by:

Karine Gallardo, National Institute for Agronomic Research, France

Jean-Christophe Avice, University of

Caen Basse-Normandie and National Institute for Agronomic Research,

France

\section{*Correspondence:}

Hari B. Krishnan, USDA-ARS, Plant

Genetics Research Unit, University

of Missouri, 108 Curtis Hall,

Columbia, MO 65211, USA

e-mail: hari.krishnan@ars.usda.gov
Expression of heterologous methionine-rich proteins to increase the overall sulfur amino acid content of soybean seeds has been only marginally successful, presumably due to low accumulation of transgenes in soybeans or due to gene silencing. Proteome rebalancing of seed proteins has been shown to promote the accumulation of foreign proteins. In this study, we have utilized RNAi technology to suppress the expression of the $\beta$-conglycinin, the abundant $7 S$ seed storage proteins of soybean. Western blot and 2D-gel analysis revealed that $\beta$-conglycinin knockdown line (SAM) failed to accumulate the $\alpha^{\prime}, \alpha$, and $\beta$-subunits of $\beta$-conglycinin. The proteome rebalanced SAM retained the overall protein and oil content similar to that of wild-type soybean. We also generated transgenic soybean lines expressing methionine-rich $11 \mathrm{kDa} \delta$-zein under the control of either the glycinin or $\beta$-conglycinin promoter. The introgression of the $11 \mathrm{kDa} \delta$-zein into $\beta$-conglycinin knockdown line did not enhance the accumulation of the $11 \mathrm{kDa} \delta$-zein. However, when the same plants were grown in sulfur-rich medium, we observed 3- to 16-fold increased accumulation of the $11 \mathrm{kDa} \delta$-zein. Transmission electron microscopy observation revealed that seeds grown in sulfur-rich medium contained numerous endoplasmic reticulum derived protein bodies. Our findings suggest that sulfur availability, not proteome rebalancing, is needed for high-level accumulation of heterologous methionine-rich proteins in soybean seeds.

Keywords: Glycine max (L.) Merr., 7S globulin, RNA interference, proteome rebalancing, sulfur assimilation, $\delta$-zein

\section{INTRODUCTION}

Due to their high protein content and relatively low cost, soybeans (Glycine max (L.) Merr.) are used as an animal feed throughout the world. Protein accounts for about $40 \%$ of the dry weight of soybean seeds. The abundant storage proteins of soybean are the salt-soluble globulins, the $7 \mathrm{~S} \beta$-conglycinin and the $11 \mathrm{~S}$ glycinin, which together could account for about $70 \%$ of the total seed proteins (Nielsen, 1996; Nielsen and Nam, 1999; Krishnan, 2000). Both these classes of proteins are encoded by multiple gene families (Harada et al., 1989; Nielsen et al., 1989). Glycinins are hexameric proteins that are classified into two groups based on DNA sequence similarities (Nielsen et al., 1989). Group-1 glycinins contain three genes, Gy1, Gy2, and Gy3, while group-2 glycinins include two genes, Gy4 and Gy5. In addition, two genes, Gy7 and Gy6, resembling group-1 glycinins are also present (Beilinson et al., 2002). The expression of Gy7 gene is significantly lower than other Gy genes while the Gy6 has been identified as a pseudogene (Beilinson et al., 2002). Each of the glycinins is synthesized as a precursor protein that is subsequently cleaved into acidic and basic subunits (Staswick et al., 1984). $\beta$ conglycinin consists $\alpha^{\prime}, \alpha$, and $\beta$ subunits (Coates et al., 1985). Unlike the glycinins, the $\beta$-conglycinins are glycoproteins (Thanh and Shibasaki, 1978). Because of their abundance, the $7 S$ and
$11 S$ globulins are mainly responsible for the nutritional quality of soybeans.

Monogastric animals including humans are unable to synthesize essential amino acids and are dependent on their feed/food to meet the essential amino acid requirements. Even though soybeans are an excellent source of high quality protein, the sulfur amino acid content of soybean seed proteins is not optimal for the formulation of animal feed. This deficiency necessitates supplementation of animal feeds with synthetic methionine that adds additional cost to the livestock producers. Consequently, there have been numerous attempts to improve the sulfur amino acid content of legume seed proteins utilizing different approaches including genetic engineering (Tabe and Higgins, 1998; Krishnan, 2005; Amir et al., 2012; Galili and Amir, 2013). One common approach involves the expression of heterologous seed proteins in transgenic soybeans (Townsend and Thomas, 1994; Dinkins et al., 2001; Kim and Krishnan, 2004; Krishnan, 2005). We have previously reported the expression a methionine-rich $\delta$-zein in soybean (Kim and Krishnan, 2004). The $\delta$-zein stably accumulated with endoplasmic derived protein bodies in transgenic soybean seeds. However, the accumulation of the $\delta$-zein was less than $0.5 \%$ of the total seed protein and did not increase the overall methionine content of soybean seed (Kim and Krishnan, 2004). 
Similarly, attempts by others to substantially increase the methionine content of soybeans by expressing heterologous proteins rich in methionine have not been successful (reviewed in Krishnan, 2005). Low gene expression of methionine-rich protein in soybeans can be a major contributing factor for the marginal increase in the methionine content in transgenic soybeans.

Several approaches to increase the amount of heterologous protein production in plants have been proposed (Streatfield, 2007). These approaches focus on boosting the heterologous gene replication, transcription, and translation and message stabilization (Streatfield, 2007). Another approach to enhance foreign protein production exploits the high protein synthesis capacity of legumes such as soybean (Schmidt and Herman, 2008; Herman, 2014). By suppressing the production of endogenous seed storage proteins, one could redirect the available protein synthesis capacity to the synthesis of introduced foreign proteins. To test this hypothesis, a green fluorescent protein (GFP)-kdel reporter was introgressed in $\beta$-conglycinin suppressed transgenic soybeans. This approach resulted in four-fold increase in GFP-kdel accumulation in transgenic soybean suggesting that proteome rebalancing can enhance foreign protein accumulation (Schmidt and Herman, 2008). Since our previous attempt to increase the sulfur amino acid content of soybean seed by expressing methioninerich $\delta$-zein was marginally successful due to low accumulation of the $\delta$-zein, we wanted to explore if proteome rebalancing could be exploited to elevate the $\delta$-zein accumulation in soybean.

In this study, we have created $\beta$-conglycinin knockdown transgenic soybean lines expressing methionine-rich $11 \mathrm{kDa} \delta$-zein. Interestingly, the expression the $11 \mathrm{kDa} \delta$-zein in $\beta$-conglycinin knockdown lines did not elevate the accumulation of the methionine-rich protein. However, when the same plants were grown in sulfur-rich medium, a drastic increase in the $11 \mathrm{kDa}$ $\delta$-zein accumulation was observed. Our results indicate that the availability of sulfur, not proteome rebalancing, is more critical for high-level accumulation of methionine-rich proteins in soybean seeds.

\section{MATERIALS AND METHODS GENERATION OF B-CONGLYCININ SUPPRESSED TRANSGENIC SOYBEANS}

To simultaneously suppress the expression of all three subunits of $\beta$-conglycinin we constructed an RNAi cassette by the following procedure. First, the intron from pKannibal (Wesley et al., 2001) was amplified employing the primer pair: $5^{\prime}$ primer $X b N d X h I N T R i$ (5'-TCTAGA ACATATGGTCCTCGAGAGTTACTAGTACCCCA-3') containing XbaI, NdeI and XhoI sites (bold) and $3^{\prime}$ primer INTRiRVSXb (5- TCTAGAGGTCGACCGGATATCCGCTTTGTTATATTAGC3) containing XbaI, SalI, and EcoRV sites (bold). The amplified intron product was cloned into pGEM-T easy to create pKINTRi. The intron was excised by digestion with $\mathrm{XbaI}$ and cloned into pHK vector. Primer pair SNd2AplhaRi (5'-GTCGACCATATG TACAGGAACCAAGCATGCCAC-3'; introduced restriction sites SalI and NdeI are underlined and bold, respectively) and Alpha'314XhRV (5'-GATATCCTCGAGTGAGGTTGGTG TGGGCGTGGG-3' ; introduced restriction sites EcoRV and XhoI are underlined and bold, respectively) was used to amplify a $314 \mathrm{bp}$ coding region of $\alpha^{\prime}$-subunit of the $\beta$-conglycinin. This 314 bp product was cloned into pGEM-Teasy vector (Promega, WI) and named as pBCON and sequenced at the University of Missouri DNA Core Facility. DNA prepared from pBCON was subjected to restriction enzyme digests with $\mathrm{NdeI}$ and XhoI or EcoRV and SalI to facilitate cloning the 314 bp fragments in the opposite orientation. The $N d e \mathrm{I}$ and $\mathrm{XhoI}$ excised fragment was ligated into the $5^{\prime}$ end of the pHK-intron while the EcoRV and SalI fragement was ligated into the $3^{\prime}$ end pHK-intron. This procedure resulted in a cassette containing a $314 \mathrm{bp} \alpha^{\prime}$-subunit of the $\beta$-conglycinin hairpin flanking the $\mathrm{pHK}$-intron. Following digestion with $\mathrm{XbaI}$ the entire $\beta$-conglycinin hairpin was cloned into the corresponding restriction site of $p Z P l a p h a^{\prime} \mathrm{P}$ binary vector (Kim and Krishnan, 2004). This final vector places the $\beta$-conglycinin hairpin under the regulatory control of the $\alpha^{\prime}$-subunit of $\beta$-conglycinin promoter and the terminator of the potato proteinase inhibitor gene (PinII). This vector also contains the bar-coding region under the regulatory control of cauliflower mosaic virus $35 \mathrm{~S}$ promoter and $3^{\prime}$-region of the nopaline synthase gene (Figure 1). The final RNAi construct was mobilized into Agrobacterium tumefaciens (strain EHA105) by triparental mating (Friedman et al., 1982). Soybean cultivar Maverick was transformed by Agrobacterium-cotyledonary node method (Hinchee et al., 1988). Regenerated transgenic soybean plants were screened for tolerance to herbicide Liberty by a leaf-painting assay as described earlier (Zhang et al., 1999). The knockout of the target proteins in glufosinate-resistance plants

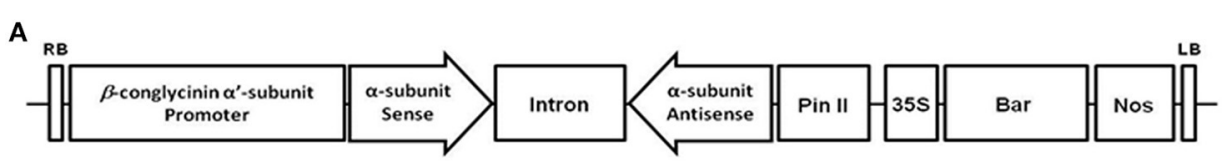

B

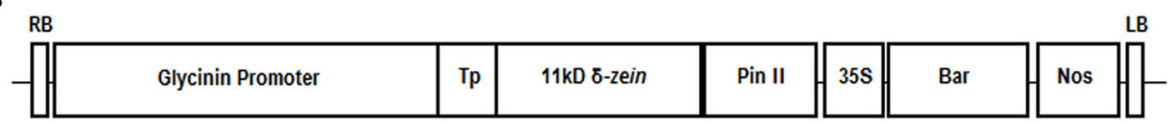

FIGURE 1 | Schematic diagram of the constructs used for the suppression of $\beta$-conglycinin soybean seeds (A) and expression of 11 kDa $\delta$-zein (B). The RNAi cassette contains a 314 bp region of the $\alpha^{\prime}$ subunit of the $\beta$-conglycinin cloned in an inverted repeat orientation and separated by the intron from pKannibal. The RNAi construct is under the control of the soybean $\beta$-conglycinin $\alpha^{\prime}$-promoter while the expression of $11 \mathrm{kDa} \delta$-zein is under the control of soybean glycinin promoter (Kim and Krishnan, 2004). The constructs also contain a gene expression cassette that includes the cauliflower mosaic virus $35 \mathrm{~S}$ promoter, the bar-coding region and the $3^{\prime}$ region of the nopaline synthase gene (nos). 
was confirmed by PCR and SDS-PAGE. For all comparisons soybean cultivar Maverick was used and referred as wild-type.

\section{RT-PCR ANALYSIS}

Total RNA was extracted from transgenic soybean seed at the mid-maturation stage (seed size $8-10 \mathrm{~mm}$ ) using a Trizol reagent (Invitrogen, Grand Island, NY, USA) following the manufacture's protocol. RNA was quantified by measuring the A260/A280 ratio using a spectrophotometer. One $\mu \mathrm{g}$ of DNase I treated RNA was used as template for RT-PCR. Primers used for alpha' subunit were Alpha'F, 5-ATGATGAGAGC GCGGTTCCCATTACTG-3 and Alpha'R, 5-TCAGTAAAAAG CCCTCAAAATTGAAGAC-3. Primers used for alpha subunit were Alpha F, 5-ATGATGAGAGCACGGTTCCCATTACTG-3 and Alpha'R. Primers used for beta subunit were BetaF, 5-ATGAT GAGAGTGCGGTTTCCTTTGTTGG-3 and BetaR, 5- TCAGTAG AGAGCACCTAAGATTGAAG-3. Primers used for glycinin 4 were SoyGy4F, 5- ATGGGGAAGCCCTTCACTCTCTCTCTTTC3 and SoyGy4R, 5- TTATGCGACTTTAACACGGGGTGAGC-3. The cycling condition of RT-PCR were $50^{\circ} \mathrm{C}$ for $30 \mathrm{~min}$ for $\mathrm{cDNA}$ production, $95^{\circ} \mathrm{C}$ for $15 \mathrm{~min}$ for inactivation of cDNA production, then 35 cycles of $94^{\circ} \mathrm{C}$ for $60 \mathrm{~s}, 60^{\circ} \mathrm{C}$ for $60 \mathrm{~s}, 72^{\circ} \mathrm{C}$, for $90 \mathrm{~s}$ with a final $72^{\circ} \mathrm{C}$ for $240 \mathrm{~s}$ extension steps.

\section{DETERMINATION OF SEED PROTEIN AND OIL CONTENT}

Soybean protein content was measured using the Leco model FP-428 nitrogen analyzer (LECO Corporation, Michigan, USA). The oil content was quantified by near-infrared reflectance (NIR) spectroscopy (Tecator AB, Hoganas, Sweden). The fatty acid profiles of soybean were determined by gas chromatograph as described previously (Lee et al., 2009). Briefly, crushed seeds were extracted overnight with $5 \mathrm{~mL}$ of chloroform: hexane: methanol $(8: 5: 2, \mathrm{v} / \mathrm{v} / \mathrm{v})$. Fatty acids from $100 \mu \mathrm{L}$ aliquots of the extract were methylated with $75 \mu \mathrm{L}$ of methanolic sodium methoxide:petroleum ether:ethyl ether $(1: 5: 2, \mathrm{v} / \mathrm{v} / \mathrm{v})$. Fatty acids were separated utilizing Agilent Series 6890 capillary gas chromatograph (Palo Alto, CA, USA) that was fitted with an AT-Silar capillary column (Alltech Associates, Deerfield, IL, USA). Standard fatty acid mixtures were used for determining relative amounts of each fatty acid. Four replicates of "Maverick" (MAV) and $\beta$-conglycinin knockdown line (SAM) were compared using the $t$ test function within JMP ${ }^{\circledR}$ software Version 9 (SAS Institute Inc., Cary, NC). Significantly different means are indicated by ${ }^{*},{ }^{* *}$, or *** ( $p \leq 0.05, p \leq 0.01, p \leq 0.001$, respectively) and insignificant differences are indicated by "NS."

\section{PROTEIN ISOLATION AND IMMUNOBLOT ANALYSIS}

Total soybean seed proteins were extracted from $10 \mathrm{mg}$ of dry seed powder with $1 \mathrm{ml}$ of SDS sample extract buffer (2\% SDS, $60 \mathrm{mM}$ Tris- $\mathrm{HCl}, \mathrm{pH} 6.8,5 \% \beta$-mecaptoethanol), followed by boiling at $100^{\circ} \mathrm{C}$ for $5 \mathrm{~min}$. After maximum speed centrifuge the supernatant was used for total seed protein fraction. The total seed protein fraction was electrophoresed with 8 or $15 \%$ SDSPAGE and visualized by staining with Coomassie Brilliant Blue. For western blot analysis, the total seed proteins were transferred to a nitrocellulose membrane after resolved by SDS-PAGE. After blocking with TBS $(10 \mathrm{mM}$ Tris- $\mathrm{HCl}, \mathrm{pH} 7.5,500 \mathrm{mM} \mathrm{NaCl})$ containing 5\% non-fat dry milk, the membrane was incubated over-night with $7 \mathrm{~S}$ globulin storage protein or the $11 \mathrm{kDa} \delta$ zein antibodies (Kim and Krishnan, 2003) that had been diluted 1:5000 in TBST (TBS with 3\% non-fat dry milk containing $0.2 \%$ Tween 20). After several washes with TBST, the membrane was incubated with goat anti-rabbit IgG-horseradish peroxidase conjugate. Immunoreactive polypeptide signals were detected by according to the SuperSignal West Pico kit's instruction (Pierce, Rockford, Il, USA).

\section{TWO-DIMENSIONAL GEL ELECTROPHORESIS, IMAGE ANALYSIS AND QUANTIFICATION OF SPOT VOLUME}

Two-dimensional gel electrophoresis of soybean seed proteins were performed as described earlier (Krishnan et al., 2009). Coomassie stained gels were destained with multiple changes of ultrapure water to remove background and scanned using an Epson Perfection V700 scanner controlled through Adobe Photoshop. Images were analyzed for proteome differences using Delta2D image analysis software. Delta2D parameters were set to maximize spot detection using global image warping and exact spot matching. Background subtraction parameters were identical for all gels and eliminated a large percentage of spots that were less than $0.05 \%$ of the total normalized spot volumes. A total of 732 remained on the fusion image of all gels included in the analysis, after background subtraction, and were used for the total volume ratio normalization. A total of 34 spots were chosen as a subset of this total, for major seed storage protein quantification, comprising nearly $50 \%$ of the total volume ratio normalized spot volume. This subset of 2-D resolved proteins were previously identified (Krishnan et al., 2009; Krishnan and Nelson, 2011) using peptide mass fingerprinting (MALDI-TOF MS) and then categorized as shown in Figure 5. The exact same spot regions were chosen from software generated fused image of all gels used in the analysis. Spot \% volume quantities were calculated within each comparison individually; Maverick $(n=3)$ and $\operatorname{SAM}(n=3)$.

\section{SULFUR TREATMENT AND PLANT GROWTH CONDITIONS}

Soybeans were grown in an environmentally controlled growth chamber at $26 \pm 2^{\circ} \mathrm{C}$ and $50 \%$ humidity. The plants received $14 \mathrm{~h}$ of daylight for the duration of the experiment. Each individual plant was grown in its own modified hydroponics container, consisting of a pot containing a 1:1 mixture of perlite:vermiculite, with a lower $2 \mathrm{~L}$ reservoir for the nutrient solution. Cotton wicks were placed in the lower portion of each pot to deliver nutrient solution to the plant prior to the root growth eventually reaching the lower reservoir. The nutrient solution composition was: $1.25 \mathrm{mM} \mathrm{Ca}\left(\mathrm{NO}_{3}\right)_{2} 4 \mathrm{H}_{2} \mathrm{O}, 1.25 \mathrm{mM} \mathrm{KNO}_{3}, 0.25 \mathrm{mM} \mathrm{KH}_{2} \mathrm{PO}_{4}$, $0.5 \mathrm{mM}$ Fe-EDTA, $0.5 \mathrm{mM} \mathrm{NH}_{4} \mathrm{NO}_{3}$, and a 1/1000th addition of a micronutrients mixture $\left(\mathrm{H}_{3} \mathrm{BO}_{3}, 2.86 \mathrm{~g} \mathrm{~L}^{-1} ; \mathrm{MnCl}_{2} 4 \mathrm{H}_{2} \mathrm{O}\right.$, $1.81 \mathrm{~g} \mathrm{~L}^{-1} ; \mathrm{ZnCl}_{2}, 0.095 \mathrm{~g} \mathrm{~L}^{-1} ; \mathrm{Cu}\left(\mathrm{NO}_{3}\right)_{2} \mathrm{xH}_{2} \mathrm{O}, 0.047 \mathrm{~g} \mathrm{~L}^{-1}$; $\mathrm{H}_{2} \mathrm{MoO} 4 \mathrm{H}_{2} \mathrm{O}, 0.09 \mathrm{~g} \mathrm{~L}^{-1}$ ). The sulfate control solution contained $0.5 \mathrm{mM} \mathrm{MgSO}_{4} 7 \mathrm{H}_{2} \mathrm{O}$, and the sulfur-rich solution contained $2.0 \mathrm{mM} \mathrm{MgSO}_{4} 7 \mathrm{H}_{2} \mathrm{O}$. The nutrient solution was replaced every 3 days to maintain a consistently fresh nutrient supply. Seeds were harvested approximately 90 days after treatments began. 


\section{AMINO ACID ANALYSIS}

Amino acid analysis was performed at the Donald Danforth Plant Science Center Proteomics and Mass Spectrometry Facility. Free amino acid content was determined following the protocol of Hacham et al. (2002). For the determination of the total amino acid content the seed powder was first subjected to hydrolysis with $6 \mathrm{~N} \mathrm{HCl}$. For the quantification of methionine and cysteine, duplicate samples were first subjected to an initial oxidation step using performic acid prior to acid hydrolysis. Amino acids were quantified using the manufacturer's instructions of the Waters AccQ-Tag Ultra Kit on an Acquity UPLC system. Samples were run in quadruplicate and subjected to appropriate statistical analysis.

\section{IMMUNOSTAINING OF PARAFFIN SECTIONS}

Greenhouse-grown soybean seeds at R6 stage (Fehr et al., 1971) were cut into several pieces and fixed in FAA (10\% formaldehyde, 50\% ethyl alcohol, and 5\% glacial acetic acid) for $8 \mathrm{~h}$ at room temperature. The tissue was dehydrated in a graded ethanol/xylene series and infiltrated with paraffin. Sections were cut with a microtome and processed for immunostaining following the protocol described earlier (Bilyeu et al., 2008). Sections were separately incubated with 1:1000 diluted antibodies raised against the $\beta$-subunit of $\beta$-conglycinin or Kunitz trypsin inhibitor. Following this step, the sections were treated sequentially with biotinylated linker, streptavidin conjugated to horseradish peroxidase, and substrate-chromogen solution (DAKO). The sections were examined under bright field optics.

\section{ELECTRON MICROSCOPY}

Mature dry seeds were surface sterilized by first sequentially incubating with $95 \%$ ethanol for $5 \mathrm{~min}$ and with $50 \%$ commercial bleach for $5 \mathrm{~min}$. Following extensive washes in distilled water the seeds were transferred to $1 \%$ water agar plates and germinated in a $30^{\circ} \mathrm{C}$ incubator for $12 \mathrm{~h}$. Seeds were sliced into several 2$4 \mathrm{~mm}$ cubes and fixed for $4 \mathrm{~h}$ in $2.5 \%$ glutaraldehyde buffered at $\mathrm{pH} 7.2$ with $50 \mathrm{mM}$ sodium phosphate. After several rinses in sodium phosphate buffer the seeds were post-fixed for $1 \mathrm{~h}$ with $1 \%$ aqueous osmium tetroxide. The seed tissue was dehydrated in a graded acetone series and infiltrated with Spurr's resin. Thin sections of the seed tissue were cut with a diamond knife and collected on 200 mesh copper grids. The grids were stained with $0.5 \%$ uranyl acetate and $0.4 \%$ lead citrate and examined at $80 \mathrm{kV}$ under JEOL $1200 \mathrm{EX}$ (Tokyo, Japan) transmission electron microscope.

\section{RESULTS \\ CREATION OF B-CONGLYCININ KNOCKDOWN SOYBEAN SEEDS}

The suppression of the 7S globulins accumulation in soybean seeds was accomplished by RNAi utilizing Agrobacteriummediated cotyledonary node transformation protocol (Hinchee et al., 1988). Seeds from several independent transgenic lines were screened for their protein composition by SDS-PAGE and immunoblot analysis using antibodies raised against the $\beta$-subunit of $\beta$-conglycinin (Figure 2). An examination of the Coomassie stained gel revealed that in $50 \%$ of the transgenic plants no significant reduction in the accumulation of $\beta$-conglycinin had occurred when compared to the wild-type

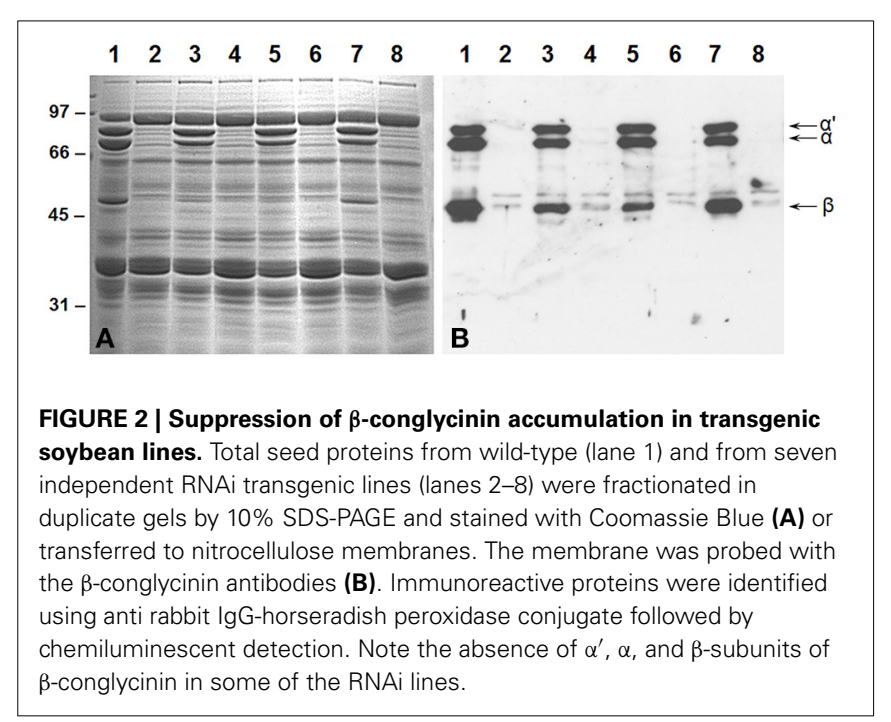

plant (Figure 2A). However, four transgenic RNAi lines showed a complete absence of the $\beta$-conglycinin accumulation in their seeds (Figure 2A). The lack of $\beta$-conglycinin in these RNAi lines was confirmed by immunoblot analysis using $\beta$-conglycinin antibodies (Figure 2B). These four lines were grown for five generations. Twenty individual $\mathrm{T} 5$ seeds from each transgenic line were subjected to Western blot analysis. Transgenic plants where all tested seeds failed to accumulate the $\beta$-conglycinin were considered to be homozygous plants. These homozygous transgenic RNAi plants are referred as SAM from this point onwards.

We investigated the mRNA levels of the major seed storage proteins between the RNAi line SAM and the wild-type control by RT-PCR. When primers specific for $g y 1, g y 2, g y 3$, and $g y 4$ were used in RT-PCR reactions, gene-specific products were amplified in both plants (Figure 3A). However, when primers specific for each of the three subunits of $\beta$-conglycinin were employed, RT-PCR products were seen only in the wildtype control and not in SAM (Figure 3B). The absence of the $\beta$-conglycinin accumulation in SAM seeds was further examined by immunocytochemical localization. Sections of soybean seed were incubated with either $\beta$-conglycinin or Kunitz trypsin inhibitor specific antibodies followed by incubation with streptavidin conjugated to horseradish peroxidase. Antibodies raised against the $\beta$-conglycinin did not detect their accumulation in the paraffin-embedded sections as evidenced by the absence of brown localization signal (Supplemental Figure 1A) while it was readily detected in the wild-type control seeds (Supplemental Figure 1B). In contrast, when the paraffin sections were incubated with Kunitz trypsin inhibitor specific antibodies positive reactions were seen in both SAM and the wild-type control seeds (Supplemental Figures 1C-D).

\section{PROTEIN, OIL AND AMINO ACID COMPOSITION OF B-CONGLYCININ KNOCKDOWN SOYBEAN SEEDS}

To investigate if knockdown of $\beta$-conglycinin resulted in any alterations of the seed components we first measured the total protein and oil content of these seeds. Both the wild-type control and SAM contain very similar concentrations of total protein and 


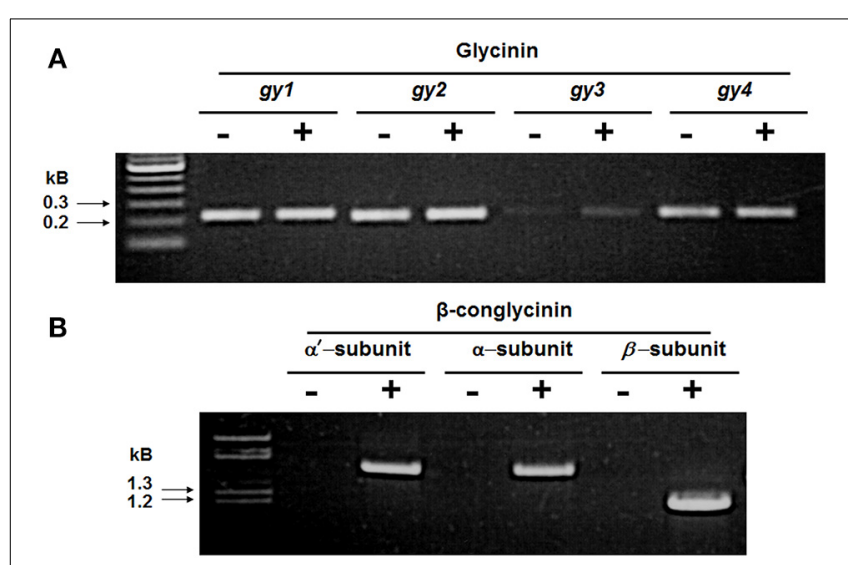

FIGURE 3 | RT-PCR analysis of 7S and 11S globulin gene expression in developing soybean seeds. Total RNA isolated from wild-type control (+) and $\beta$-conglycinin knockdown transgenic soybean line SAM (-) was used in RT-PCR analysis. The upper panel (A) shows the RT-PCR products for the gy1, gy2, gy3, and gy4 genes (11S globulin) and the lower panel (B) shows the RT-PCR products for the $\alpha^{\prime}, \alpha$, and $\beta$-subunits of $\beta$-conglycinin (7S globulin).

Table 1 | Protein, amino acid and oil content in wild-type and $\beta$-conglycinin knockdown line (SAM).

\begin{tabular}{|c|c|c|c|c|}
\hline Seed Component & Wild-type & SAM & $\begin{array}{l}\text { Significance } \\
\text { level }\end{array}$ & $p$-value \\
\hline Protein $^{a}$ & $35.9 \pm 0.4$ & $36.0 \pm 0.4$ & NS & 0.84 \\
\hline Oila & $19.4 \pm 0.1$ & $19.7 \pm 0.3$ & NS & 0.05 \\
\hline $\begin{array}{l}\text { Total Amino Acid (Free }+ \\
\text { Protein bound) }\end{array}$ & $2410.5 \pm 113.4$ & $2794.5 \pm 130.1$ & $* *$ & 4.53E-03 \\
\hline \multicolumn{5}{|l|}{ Fatty acids ${ }^{a}$} \\
\hline Palmitic Acid (16:0) & $11.6 \pm 0.2$ & $10.6 \pm 0.1$ & $* * *$ & 3.76E-04 \\
\hline Stearic Acid (18:0) & $4.2 \pm 0.1$ & $4.5 \pm 0.3$ & NS & 0.08 \\
\hline Oleic Acid (18:1) & $20.5 \pm 0.9$ & $23.2 \pm 0.7$ & $* *$ & 3.38E-03 \\
\hline Linoleic Acid (18:2) & $55.9 \pm 0.6$ & $55.0 \pm 0.4$ & $*$ & 0.02 \\
\hline Linolenic Acid (18:3) & $7.9 \pm 0.2$ & $6.7 \pm 0.1$ & $* * *$ & $6.25 \mathrm{E}-04$ \\
\hline
\end{tabular}

Significantly different means are indicated by ${ }^{*},{ }^{* *}$, or ${ }^{* *}(p \leq 0.05, p \leq 0.01$, $p \leq 0.001$, respectively) and insignificant differences are indicated by "NS."

${ }^{a}$ expressed as percentage.

${ }^{b}$ nanomoles/mg seed.

oil (Table 1). Total amino acid content was significantly higher in $\beta$-conglycinin knockdown line (Table 1). Analysis of the five major fatty acids in these seeds by gas chromatograph also showed significant differences. The concentration of palmitic, linoleic and linolenic acids was higher in the wild-type while oleic acid content was higher in SAM (Table 1).

Previous studies have shown that soybean mutants lacking the seed storage proteins accumulate high levels of free amino acids (Takahashi et al., 2003; Schmidt et al., 2011). To examine if similar situation also occurred in the $\beta$-conglycinin knockdown soybean line we determined the total and free amino acid content (Figure 4). An examination of the total amino acid composition revealed a slight increase in several of the amino acids in SAM when compared to that of wild-type control (Figure 4A). In contrast, a comparison of the free amino acid composition revealed
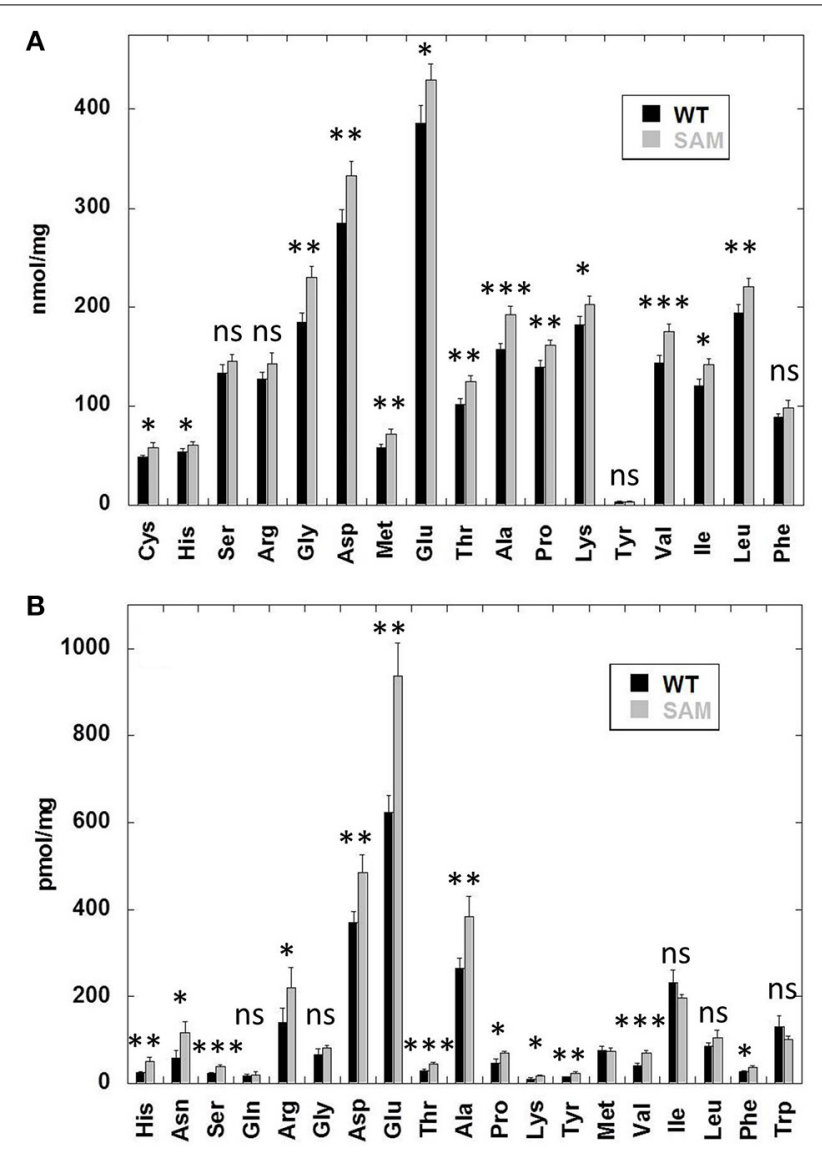

FIGURE 4 | Free and total amino acid composition of soybean seeds. Dry seed powder from quadruplicate samples was analyzed by HPLC to measure the total (A) and free amino acid (B) from wild-type (WT) and $\beta$-conglycinin knockdown soybean line (SAM).

significant increases in the concentration of several amino acids in SAM seeds especially glutamic acid, aspartic acid, asparagine, arginine, and alanine (Figure 4B). In previous studies arginine represented the main amino acid that contributed to the accumulation of high levels of free amino acids (Takahashi et al., 2003; Schmidt et al., 2011). However, in our studies we observed that arginine was not the most abundant amino acid in the overall free amino acid pool in SAM. Few other amino acids (glutamic acid, aspartic acid, asparagine, and alanine) also contributed significantly to the elevated levels of free amino acid content in SAM seeds (Figure 4B).

\section{D-GEL ANALYSIS OF SOYBEAN SEED PROTEIN COMPOSITION}

Two dimensional-gel analysis was performed to evaluate the changes in the protein composition of RNAi soybean line with that of the wild-type control (Figure 5). This analysis clearly demonstrated that $\beta$-conglycinin knockdown RNAi line lacked all the three subunits ( $\alpha^{\prime}, \alpha$, and $\beta$-subunits) of $\beta$-conglycinin. Previous studies have shown that suppression of the seed $7 \mathrm{~S}$ and $11 \mathrm{~S}$ seed storage proteins resulted an increase in the accumulation of lipoxygenase, sucrose binding protein, basic 7S globulin, Kunitz trypsin inhibitor, soybean lectin, Gly m Bd 30k, 


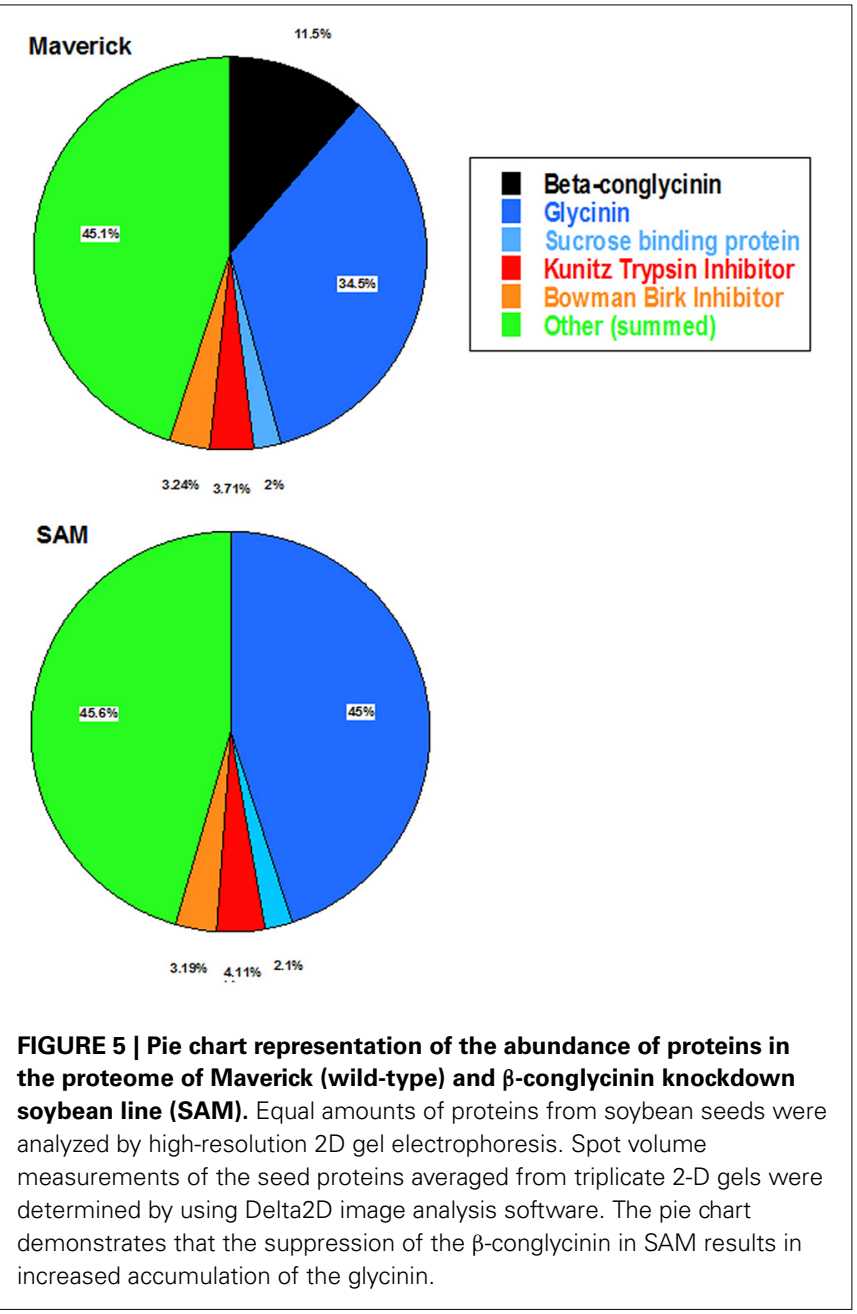

Glc-binding protein and seed maturation-associated protein in these seeds (Takahashi et al., 2003; Schmidt et al., 2011). To see if similar changes are also occurred in SAM 2D fractionated soybean seed proteins from SAM and wild-type control (run in triplicate) were analyzed with high-resolution image analysis software (Delta 2D). This analysis indicated that absence of the three subunits of $\beta$-conglycinin was associated with an increase in the glycinin content (Figure 5). A comparison of seed protein profiles between SAM and wild-type control did not reveal any substantial differences between other seed proteins (Figure 5).

\section{PRODUCTION OF TRANSGENIC SOYBEAN LINES EXPRESSING THE 11 KDA $\delta$-ZEIN AND IT'S INTROGRESSION INTO SAM}

We had earlier generated transgenic soybean plants expressing $11 \mathrm{kDa} \delta$-zein under the control of the $\beta$-conglycinin promoter (Kim and Krishnan, 2004). Since the $\beta$-conglycinin promoter was also used for suppressing the expression of $\beta$-conglycinin we wanted to use another seed-specific promoter to express the $11 \mathrm{kDa} \delta$-zein. For this purpose a plasmid consisting of soybean glycinin promoter, the coding region of the $11 \mathrm{kDa}$ $\delta$-zein, the $3^{\prime}$ region of the potato proteinase inhibitor gene, together with the cassette containing bar herbicide resistance

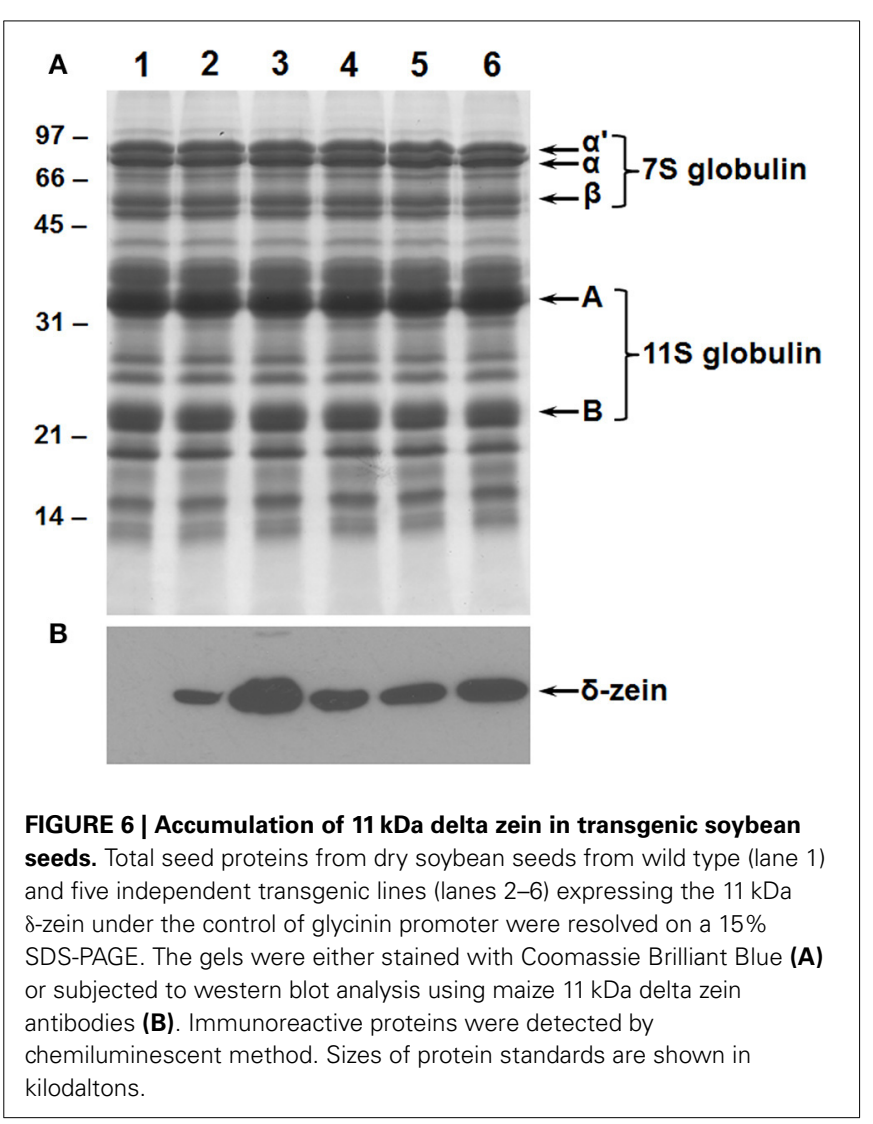

gene was constructed (Figure 1) and introduced into soybean cv. Williams 82 as described earlier (Kim and Krishnan, 2004). The accumulation of the $11 \mathrm{kDa} \delta$ zein in five independent transgenic events was verified by western blot analysis using antibodies raised against the purified $11 \mathrm{kDa} \delta$-zein (Figure 6). The $11 \mathrm{kDa} \delta$-zein expressing soybean lines were grown in the greenhouse for another three generations to produce T4 plants.

Earlier studies have shown proteome rebalancing in seeds can be exploited for elevated expression of foreign proteins (Goossens et al., 1999; Tada et al., 2003; Schmidt and Herman, 2008). We wanted to test if the $\delta$-zein introgression into the $\beta$-conglycinin knockdown RNAi line would enhance the accumulation of the $\delta$-zein. For this purpose, crosses were made between homozygous $11 \mathrm{kDa} \delta$-zein expressing soybean plants and $\beta$-conglycinin knockdown RNAi soybean plants. Seeds from successful crosses were germinated and a small segment of the seed was assayed by immunoblot analysis for the absence of $\beta$-conglycinin and the accumulation of $11 \mathrm{kDa} \delta$-zein. Seeds with the desired combination were grown in the green house and subjected to recurrent selection until homozygous plants with the desired traits were obtained.

The accumulation of the $11 \mathrm{kDa} \delta$-zein in the $\beta$-conglycinin knockdown RNAi soybean plant was examined by immunoblot analysis. The $11 \mathrm{kDa} \delta$-zein was readily detected in both original transgenic soybean plants and in $\beta$-conglycinin knockdown RNAi background. However, the $11 \mathrm{kDa} \delta$-zein did not accumulate at higher amounts in soybean seeds lacking $\beta$-conglycinin, 
indicating that proteome rebalancing did not enhance the accumulation of the $11 \mathrm{kDa} \delta$-zein.

It has been shown that availability of methionine and cysteine in legumes is the major limiting factor in enhancing the sulfur content of legumes (Tabe et al., 2002). We therefore, examined if the accumulation of the $11 \mathrm{kDa} \delta$-zein can be promoted by providing the developing plants with sulfaterich solution, which can be assimilated for sulfur metabolism. For this purpose, we grew the soybean plants in hydroponics under two levels of sulfate. In seeds from plants grown in presence $0.5 \mathrm{mM}$ magnesium sulfate, the accumulation of the $11 \mathrm{kDa}$ $\delta$-zein was higher in wild-type background than in $\beta$-conglycinin knockdown background (Figures 7A-B). Interestingly, in seeds from soybean plants grown in presence of $2 \mathrm{mM}$ magnesium sulfate there was a drastic increase in the accumulation of the $11 \mathrm{kDa}$ protein. This difference in the accumulation of the $\delta$-zein was much more striking in $\beta$-conglycinin knockdown background (Figure 7B). Densitometer scans of the immunoblots revealed that the seeds from plants grown in presence of $2 \mathrm{mM}$ magnesium sulfate had about 3- to 16 -fold increases in the accumulation of the $11 \mathrm{kDa} \delta$-zein in the original and introgressed lines, respectively (Figure 7B). In contrast, the overall protein content of soybean seeds was not affected by sulfate treatment. Soybean plants grown in presence of $2 \mathrm{mM}$ magnesium sulfate had $34.9 \pm 0.6 \%$ while those grown in sulfate-rich solution contained $35.0 \pm 0.4 \%$ protein. Our preliminary analysis also revealed that the transgenic soybean plants grown in sulfate-rich solution exhibited 1.2 fold-increase in the total sulfur amino acid content when

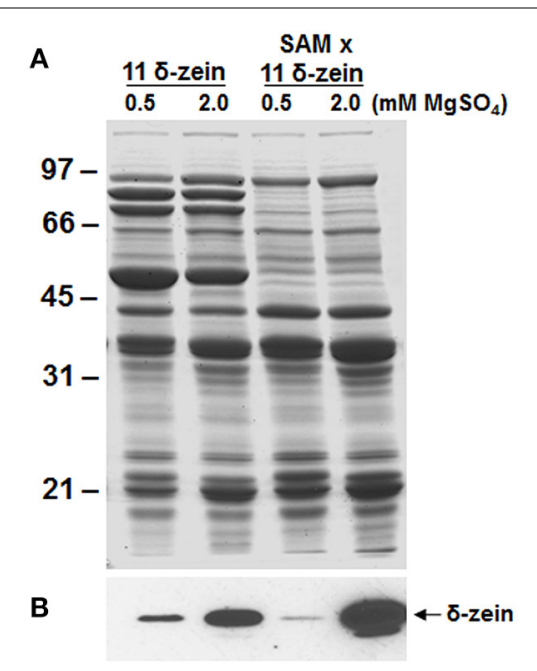

FIGURE 7 | Effect of sulfur nutrition on the accumulation of the $\mathbf{1 1} \mathbf{k D a}$ $\delta$-zein in transgenic soybean seeds. Total seed proteins from $11 \mathrm{kDa}$ $\delta$-zein expressing line and the $11 \mathrm{kDa} \delta$-zein introgressed into the $\beta$-conglycinin knockdown soybean line (SAM) that were grown hydroponically in presence of 0.5 or $2 \mathrm{mM}$ magnesium sulfate were fractionated in duplicate gels by $15 \%$ SDS-PAGE and stained with Coomassie Blue (A) or transferred to nitrocellulose membranes. The membrane was probed with the $11 \mathrm{kDa} \delta$-zein specific antibodies (B). Immunoreactive proteins were identified using anti rabbit lgG-horseradish peroxidase conjugate followed by chemiluminescent detection. compared with plants grown in presence of $0.5 \mathrm{mM}$ magnesium sulfate.

\section{SULFUR SUPPLEMENTATION PROMOTES THE FORMATION OF PROTEIN BODIES}

Previously we showed that expression of $11 \mathrm{kDa} \delta$-zein results in the formation of endoplasmic reticulum derived protein bodies (Kim and Krishnan, 2004). Immunocytochemical localization studies also confirmed that $\delta$-zein is localized within these protein bodies (Kim and Krishnan, 2004). Since sulfur supplementation resulted in a drastic increase in the accumulation of the $11 \mathrm{kDa} \delta$-zein in transgenic soybean plants, we examined if this change was accompanied by an increase in the number of protein bodies. Thin-sections of soybean seeds expressing the $11 \mathrm{kDa}$ $\delta$-zein in $\beta$-conglycinin knockdown background grown in 0.5 and $2 \mathrm{mM}$ of magnesium sulfate were examined by transmission electron microscopy (Figure 8). Electron microscopy observation of thin sections of soybean seeds grown in presence of $0.5 \mathrm{mM}$ magnesium sulfate revealed prominent oil bodies and large protein storage vacuoles, the storage compartment for the native glycinin and $\beta$-conglycinin (Figure 8A). In addition few spherical electron-dense spherical protein bodies were also observed in the cotyledonary cells (Figure 8A). An examination of seeds grown in $2 \mathrm{mM}$ of magnesium sulfate revealed the presence of numerous protein bodies (Figure 8B). Interestingly soybean seeds from plants grown in presence of $2 \mathrm{mM}$ magnesium sulfate contained numerous small electron-dense protein bodies within vacuoles (Figure 8C).

\section{DISCUSSION}

Soybeans provide several advantages for the production of recombinant proteins for diagnostics, therapeutics, and industrial applications (Bost and Piller, 2011). Chief among them is the low cost of recombinant protein production and the ability to produce and store large amounts of transgenic proteins in seeds (Bost and Piller, 2011). Several laboratories have generated transgenic soybean plants that express 1 to $4 \%$ of the total soluble protein as recombinant protein (Piller et al., 2005; Ding et al., 2006; Garg et al., 2007; Moravec et al., 2007; Rao and Hildebrand, 2009; Cunha et al., 2010). Other groups have identified seed fill sensor proteins, such as cruiferin, that may be usable to alter seed composition (Lin et al., 2013). In spite of these achievements, problems remain in obtaining and maintaining highlevel heterologous expression in seeds. In cases where high-level expression of transgene is achieved, invariably it is accomplished by down regulation of endogenous reserve proteins (Tabe and Droux, 2001; Hagan et al., 2003; Scossa et al., 2008).

Several naturally occurring, as well as induced, mutations that affect the accumulation of soybean seed storage proteins have been previously described (Kitamura and Kaizuma, 1981; Odanaka and Kaizuma, 1989; Takahashi et al., 1994; Yagasaki et al., 1996; Hayashi et al., 1998). By integrating these mutations by crossbreeding, a soybean line that lacks all the glycinin and $\beta$ conglycinin subunits has been developed (Takahashi et al., 2003). This soybean line, in spite of lacking all the major seed storage proteins, was able to grow and reproduce normally. Interestingly, the nitrogen content of the seeds was found to be similar to that 

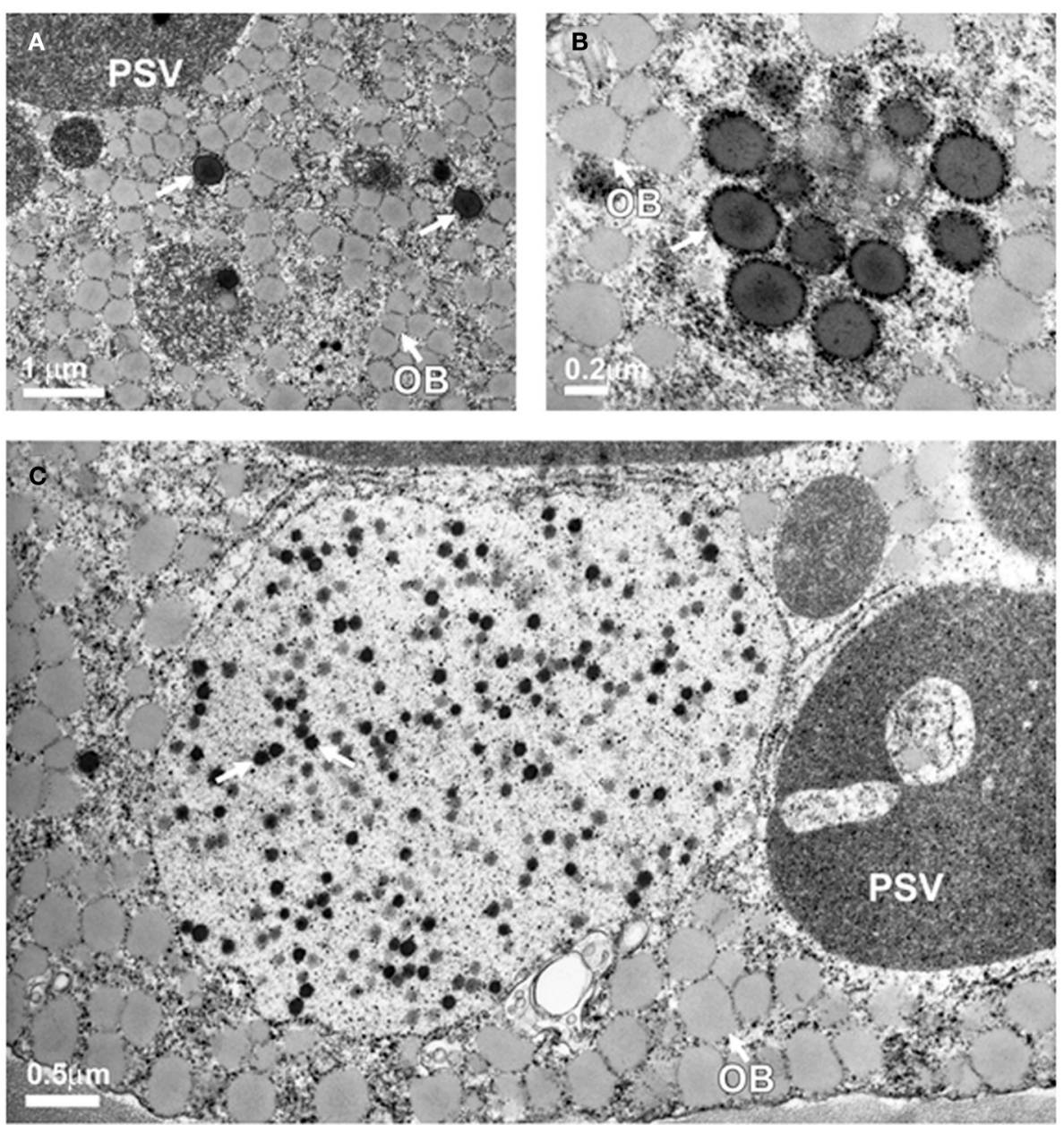

FIGURE 8 | Transmission electron microscopy observation of protein bodies in transgenic soybean seeds. Seeds grown in presence of $0.5 \mathrm{mM}$ magnesium sulfate contain a few endoplasmic reticulum-derived spherical protein bodies (A, arrows) while seeds grown in presence of $2 \mathrm{mM}$ magnesium sulfate reveal numerous dark staining spherical protein bodies (B,C). PSV, protein storage vacuole; OB, oil bodies; PB, protein body. of the wild-type cultivars (Takahashi et al., 2003). Additionally, the absence of the abundant seed proteins resulted in preferential increase in the accumulation of lipoxygenase, sucrose binding protein, agglutinin and the basic $7 \mathrm{~S}$ globulin. Similarly, a soybean line lacking both glycinin and beta-conglycinin (SP-) was developed by RNA interference (Schmidt et al., 2011). The absence of glycinin and $\beta$-conglycinin in the SP- line was accompanied by selective increase in the accumulation of a few proteins similar to the situation encountered through integration of mutations (Takahashi et al., 2003). In both cases, the absence of major seed storage proteins was compensated by the accumulation of free amino acids with arginine accounting for more than $50 \%$ of the free amino acid content (Takahashi et al., 2003; Schmidt et al., 2011).

Here we used RNAi to suppress expression of the $\alpha, \alpha^{\prime}$, and $\beta$-subunits of $\beta$-conglycinin in soybean seed. The resulting SAM line showed clear knockdown of these subunits, as confirmed by RT-PCR, immunoblot, and 2D-gel analyses (Figures 2, 3, 5). Although the SAM line retained normal overall protein and oil seed content compared to wild-type seed (Table 1), the distribution of amino acids in SAM showed increases in glutamic acid, aspartic acid, asparagine, and alanine compared to wild-type (Figure 4). In contrast to Takahashi et al. (2003), only a modest increase in arginine content in the $\beta$-conglycinin knockdown soybean line was observed (Figure 4). Moreover, this comparison revealed slight increase in the methionine and cysteine content in the $\beta$-conglycinin knockdown soybean line compared to wildtype. Glycinin is relatively rich in sulfur, while the $\beta$-conglycinin is poor in sulfur containing amino acids (Krishnan, 2005). Some earlier reports suggest that elimination of $\beta$-conglycinin could led to increased levels of sulfur-containing amino acids in soybean seeds (Ogawa et al., 1989; Panthee et al., 2004). Our analysis of the SAM seeds indicates that elimination of $\beta$-conglycinin only marginally increases the sulfur amino acid content of soybean seeds. This observation is consistent with other studies indicating that a lack of either glycinin or $\beta$-conglycinin has little effect on total amino acid composition of soybean seeds (Takahashi et al., 2003; Schmidt et al., 2011). 
RNA interference has been successfully employed to alter the nutritional quality of the seed (Segal et al., 2003; Frizzi et al., 2010). For example, the suppression of the barley C-hordeins resulted in elevated levels of several essential amino acids in the transgenic seeds (Lange et al., 2007). Similarly, high-level expression of human growth hormone polypeptide was achieved in a glutelin and prolamin knockdown rice line (Shigemitsu et al., 2012). In contrast, our approach to increase the accumulation of the methionine-rich maize $\delta$-zein in the $\beta$-conglycinin knockdown soybean line showed no appreciable changes in expression levels of the maize protein.

Previous attempts to overexpress foreign proteins in seed protein knockdown soybean lines have also met with mixed results. The introgression of green fluorescent protein (GFP$\mathrm{kdel})$ in a $\beta$-conglycinin suppressed soybean line resulted in a four-fold increase in the accumulation of the GFP-kdel (Schmidt and Herman, 2008). Subsequently, researchers from the same group reported that introgression of GFP in a glycinin and $\beta$-conglycinin knockdown (SP-) line did not lead to accumulation of GFP (Schmidt et al., 2011). The results from these studies clearly indicates that the capacity to overexpress foreign proteins in soybeans will be influenced by several factors such as the nature of the endogenous seed protein targeted for suppression by RNAi, the amino acid composition, and the localization of the heterologous protein.

An obstacle in achieving high-level expression of methioninerich $\delta$-zein may be the paucity of sulfur-containing amino acids in developing soybean seeds to support its production. Legumes in general are poor in sulfur-containing amino acids (Shewry, 2000). Often the expression of foreign proteins rich in sulfur amino acids is accompanied by reduction in the endogenous sulfur-rich proteins, indicating that sulfur availability in seeds is the limiting factor. Sulfur nutrition or methionine supplementation has been shown to influence the accumulation of methionine-rich storage proteins in legumes (Chiaiese et al., 2004; Amira et al., 2005). Common bean (Phaseolus vulgaris L.) accumulates large amounts of a $\gamma$-glutamyl dipeptide of S-methyl-cysteine, a non-protein amino acid (Taylor et al., 2008). Interestingly, the removal of $7 \mathrm{~S}$ globulin and phytohemagglutinin in Phaseolus vulgaris enhanced the accumulation of sulfur-rich proteins (Marsolais et al., 2010). Additionally, an increase in cysteine and methionine was reported which occurred at the expense of S-methylcysteine. This indicates a redirection of sulfur from $\gamma$-glutamyl-S-methyl-cysteine to the protein cysteine pool.

When the transgenic soybean seeds were grown in presence of excess sulfur there was a significant increase in the accumulation of the methionine-rich $\delta$-zein (Figure 7 ). Transmission electron microscopy observation (Figure 8) also confirmed that sulfur supplementation to soybean plants drastically increased the number of endoplasmic reticulum derived protein bodies, the site of $\delta$-zein accumulation. These observations indicate that the intrinsic capacity to synthesize sulfur containing amino acids is very high but limited by the level of sulfate in the nutrient solution. Previous studies indicate that metabolic engineering of the sulfur assimilatory pathway can be used as a tool to increase the sulfur amino acid content of seeds (Avraham et al., 2005; Tabe et al., 2010; Song et al., 2013). Recently, it was reported that soybean seeds expressing feed-back-insensitive cystathionine- $\gamma$-synthase exhibited 1.8 to 2.3 -fold increases in the total methionine content of their seeds (Song et al., 2013).

In this study we have shown the importance of sulfur nutrition on the accumulation of heterologous methionine-rich protein in soybean. Our results suggest that sink strength is not limiting for accumulation of methionine-rich $\delta$-zein. Instead the limiting factor appears to be sulfate availability. Sulfur assimilation is inter-connected with nitrogen (N) and carbon (C) metabolism (Kopriva et al., 2002; Hawkesford and De Kok, 2006). Because of this inter-connection sulfur deficiency manifests in the form of poor plant growth and lower yields (Zhao et al., 1999a,b; Hawkesford, 2000). Insufficient sulfur supply causes changes in amino acid pools and alters the seed protein composition (Gayler and Sykes, 1985; Spencer et al., 1990). Additionally, sulfur nutrition has a pronounced effect on legume-rhizobium symbiosis. Legumes grown in sulfur-rich media exhibit elevated nitrogen fixation due to an increase in nodule development and function (Scherer et al., 2008; Varin et al., 2010). Compared to other organs nodules have much greater thiol concentrations due to active thiol synthesis in nodule tissue (Matamoros et al., 1999). Higher yields observed in legumes grown in sulfur-rich environment may be attributed to remobilization of nutrients from the nodules and other source organs to seeds. In a recent study, it was demonstrated that the response of plants to sulfur deficiency is dependent on the developmental stage of the plant (Zuber et al., 2013). Sulfur deficiency imposed at the mid-developmental stage of a model legume, Medicago truncatula, decreased yield and altered the allocation of nitrogen and carbon to seeds (Zuber et al., 2013). Interestingly, sulfur deficiency imposed during the reproductive period had little influence on the yield and nutrient allocation (Zuber et al., 2013).

Elevating the accumulation of sulfur-rich proteins in legumes possesses unique challenges. Recently, we reported a successful strategy to increase the sulfur amino acid content of soybean seed proteins by overexpressing a cytosolic isoform of $\mathrm{O}$-acetylserine sulfhydrylase (Kim et al., 2012). These transgenic soybean plants contained elevated levels of sulfur-containing amino acids that promoted the accumulation of Bowman-Birk protease inhibitor, a cysteine-rich protein (Kim et al., 2012). Thus, introgression of foreign proteins rich in sulfur-containing amino acids into the $O$-acetylserine sulfhydrylase overexpressing soybean line may offer a viable strategy to increase the sulfur amino acid content of soybean seeds. It is worthwhile to note that co-transformation of potato plants with methionine insensitive cystathionine $\gamma$-synthase $\left(\mathrm{CgS}_{\Delta 90}\right)$ and $15 \mathrm{kD} \beta$-zein resulted in elevation of protein-bound methionine content (Dancs et al., 2008).

\section{AUTHOR CONTRIBUTIONS}

Won-Seok kim, Joseph M. Jez and Hari B. Krishnan designed research; Won-Seok kim and Hari B. Krishnan performed research; Hari B. Krishnan and Joseph M. Jez analyzed the data and wrote the paper.

\section{ACKNOWLEDGMENTS}

The authors thank Nathan Oehrle for technical assistance and Jason Gillman for help with statistical analysis. Soybean transformation and electron microscopy were carried out at 
the University of Missouri Plant Transformation and Electron Microscopy Core Facilities, respectively. Amino acid analysis was performed at the Proteomics and Mass Spectrometry facility at the Danforth Center, St. Louis, Missouri. Names are necessary to report factually on available data; however, either the University of Missouri or USDA neither guarantees nor warrants the standard of product and the use of the name by the University of Missouri or USDA implies no approval of the product to the exclusion of others that may be suitable.

\section{SUPPLEMENTARY MATERIAL}

The Supplementary Material for this article can be found online at: http://www.frontiersin.org/journal/10.3389/fpls.2014. 00633/abstract

\section{REFERENCES}

Amir, R., Han, T., and Ma, F. (2012). Bioengineering approaches to improve the nutritional values of seeds by increasing their methionine content. Mol. Breed. 29, 915-924. doi: 10.1007/s11032-011-9690-7

Amira, G., Ifat, M., Tal, A., Hana, B., Shmuel, G., and Rachel, A. (2005). Soluble methionine enhances accumulation of a $15 \mathrm{kDa}$ zein, a methionine-rich storage protein, in transgenic alfalfa but not in transgenic tobacco plants. J. Exp. Bot. 56, 2443-2452. doi: 10.1093/jxb/eri237

Avraham, T., Badani, H., Galili, S., and Amir, R. (2005). Enhanced levels of methionine and cysteine in transgenic alfalfa (Medicago sativa L.) plants overexpressing the Arabidopsis cystathionine $\Upsilon$-synthase gene. Plant Biotech. J. 3, 71-79. doi: 10.1111/j.1467-7652.2004.00102.x

Beilinson, V., Chen, Z., Shoemaker, C., Fischer, L., Goldberg, B., and Nielsen, C. (2002). Genomic organization of glycinin genes in soybean. Theor. Appl. Genet. 104, 1132-1140. doi: 10.1007/s00122-002-0884-6

Bilyeu, K. D., Zeng, P., Coello, P., Zhang, Z. J., Krishnan, H. B., Bailey, A., et al. (2008). Quantitative conversion of phytate to inorganic phosphorus in soybean seeds expressing a bacterial phytase. Plant Physiol. 146, 468-477. doi: 10.1104/pp.107.113480

Bost, K., and Piller, K. (2011). "Protein expression systems: why soybean seeds?" in Soybean - Molecular Aspects of Breeding ISBN: 978-953-307-240-1, ed A. Sudaric (Rijeka: InTech), 1-18. doi: 10.5772/15376

Chiaiese, P., Ohkama-Ohtsu, N., Molvig, L., Godfree, R., Dove, H., Hocart, C., et al. (2004). Sulphur and nitrogen nutrition influence the response of chickpea seeds to an added, transgenic sink for organic sulphur. J. Exp. Bot. 55, 1889-1901. doi: 10.1093/jxb/erh198

Coates, J. B., Medeiros, J. S., Thanh, V. H., and Nielsen, N. C. (1985). Characterization of the subunits of $\beta$-conglycinin. Arch. Biochem. Biophys. 243, 184-194. doi: 10.1016/0003-9861(85)90787-8

Cunha, N. B., Araujo, A. C. G., Leite, A., Murad, A. M., Vianna, G. R., and Rech, E. L. (2010). Correct targeting of proinsulin in protein storage vacuoles of transgenic soybean seeds. Genet. Mol. Res. 9, 1163-1170. doi: 10.4238/vol9-2gmr849

Dancs, G., Kondrák, M., and Bánfalvi, Z. (2008). The effects of enhanced methionine synthesis on amino acid and anthocyanin content of potato tubers. BMC Plant Biol. 8:65 doi: 10.1186/1471-2229-8-65

Ding, S. H., Huang, L. Y., Wang, Y. D., Sun, H. C., and Xiang, Z. H. (2006). Highlevel expression of basic fibroblast growth factor in transgenic soybean seeds and characterization of its biological activity. Biotechnol. Lett. 28, 869-875. doi: 10.1007/s10529-006-9018-6

Dinkins, R. D., Reddy, R., Meurer, C. A., Yan, B., Trick, H., Thibaud-Nissen, F., et al. (2001). Increased sulfur amino acids in soybean plants overexpressing the maize $15 \mathrm{kD}$ zein protein. In Vitro Cell. Dev. Biol. Plant 37, 742-747. doi: 10.1007/s11627-001-0123-x

Fehr, W. R., Caviness, C. E., Burmood, D. T., and Pennington, J. S. (1971). Stage of development descriptions for soybeans, Glycine max (L.) Merrill. Crop Sci. 11, 929-931. doi: 10.2135/cropsci1971.0011183X001100060051x

Friedman, A. M., Long, S. R., Brown, S. E., Buikema, W. J., and Ausubel, F. M. (1982). Construction of broad host range cosmid cloning vector and its use in the genetic analysis of Rhizobium mutants. Gene 18, 289-296. doi: 10.1016/0378-1119(82)90167-6
Frizzi, A., Caldo, R. A., Morrell, J. A., Wang, M., Lutfiyya, L. L., Brown, W. E., et al. (2010). Compositional and transcriptional analyses of reduced zein kernels derived from the opaque2 mutation and RNAi suppression. Plant Mol. Biol. 73, 569-585. doi: 10.1007/s11103-010-9644-1

Galili, G., and Amir, R. (2013). Fortifying plants with the essential amino acids lysine and methionine to improve nutritional quality. Plant Biotech. J. 11, 211-222. doi: 10.1111/pbi.12025

Garg, R., Tolbert, M., Oakes, J. L., Clemente, T. E., Bost, K. L., and Piller, K. J., (2007). Chloroplast targeting of FanC, the major antigenic subunit of Escherichia coli K99 fimbriae, in transgenic soybean. Plant Cell Rep. 26, 1011-1023. doi: 10.1007/s00299-007-0322-y

Gayler, K. R., and Sykes, G. E. (1985). Effects of nutritional stress on the storage proteins of soybeans. Plant Physiol. 78, 582-585. doi: 10.1104/pp. 78.3.582

Goossens, A., Van Montagu, M., and Angenon, G. (1999). Co-introduction of an antisense gene for an endogenous seed storage protein can increase expression of a transgene in Arabidopsis thaliana seeds. FEBS Lett. 456, 160-164. doi: 10.1016/S0014-5793(99)00943-6

Hacham, Y., Avraham, T., and Amir, R. (2002). The N-terminal region of Arabidopsis cystathionine $\Upsilon$-synthase plays an important regulatory role in methionine metabolism. Plant Physiol. 128, 454-462. doi: 10.1104/pp. 010819

Hagan, N. D., Upadhyaya, N., Tabe, L. M., and Higgins, T. J. (2003). The redistribution of protein sulfur in transgenic rice expressing a gene for a foreign, sulfur-rich protein. Plant J. 34, 1-11. doi: 10.1046/j.1365-313X.2003. 01699.x

Harada, J. J., Baker, S. J., and Goldberg, R. B. (1989). Soybean beta-conglycinin genes are clustered in several DNA regions and are regulated by transcriptional and posttranscriptional processes. Plant Cell 1, 415-425.

Hawkesford, M. J. (2000). Plant responses to sulphur deficiency and the genetic manipulation of sulphate transporters to improve Sutilization efficiency. J. Exp. Bot. 51, 131-138. doi: 10.1093/jexbot/51. 342.131

Hawkesford, M. J., and De Kok, L. J. (2006). Managing sulphur metabolism in plants. Plant Cell Environ. 29, 382-395. doi: 10.1111/j.1365-3040.2005.01470.x

Hayashi, M., Harada, K., Fujiwara, T., and Kitamura, K. (1998). Characterization of a 7S globulin-deficient mutant of soybean (Glycine max (L.) Merrill). Mol. Genet. Genomics 258, 208-214. doi: 10.1007/s0043800 50724

Herman, E. M. (2014). Soybean seed proteome rebalancing. Front. Plant Sci. 5:437. doi: 10.3389/fpls.2014.00437

Hinchee, M. A. W., Connor-Ward, D. V., Newell, C. A., McDonnell, R. E., Sato S. J., Gasser, C. S., et al. (1988). Production of transgenic soybean plants using Agrobacterium-mediated DNA transfer. Biotechnology 6, 915-922. doi: 10.1038/nbt0888-915

Kim, W. S., Chronis, D., Juergens, M., Schroeder, A. C., Hyun, S. W., Jez, J. M., et al. (2012). Transgenic soybean plants overexpressing $O$-acetylserine sulfhydrylase accumulate enhanced levels of cysteine and Bowman-Birk protease inhibitor in seeds. Planta 235, 13-23. doi: 10.1007/s00425-0111487-8

Kim, W. S., and Krishnan, H. B. (2003). Allelic variation and differential expression of methionine-rich $\delta$-zeins in maize inbred lines B73 and W23al. Planta 217, 66-74. doi: 10.1007/s00425-002-0971

Kim, W. S., and Krishnan, H. B. (2004). Expression of an $11 \mathrm{kDa}$ methionine rich delta-zein in transgenic soybean results in the formation of two types of novel protein bodies in transitional cells situated between the vascular tissue and storage parenchyma cells. Plant Biotech. J. 2, 199-210. doi: 10.1111/j.14677652.2004.00063.x

Kitamura, K., and Kaizuma, N. (1981). Mutant strains with low level of subunits of 7S globulin in soybean (Glycine max Merr.) seed. Jpn. J. Breed. 31, 353-359. doi: 10.1270/jsbbs 1951.31 .353

Kopriva, S., Suter, M., von Ballmoos, P., Hesse, H., Krähenbühl, U., Rennenberg, H., et al. (2002). Interaction of sulfate assimilation with carbon and nitrogen metabolism in Lemna minor. Plant Physiol. 130, 1406-1413. doi: 10.1104/pp.007773

Krishnan, H. B. (2000). Biochemistry and molecular biology of soybean seed storage proteins. J. New Seeds 2, 1-25. doi: 10.1300/J153v02n03_01

Krishnan, H. B. (2005). Engineering soybean for enhanced sulfur amino acid content. Crop Sci. 45, 454-461. doi: 10.2135/cropsci2005.0454 
Krishnan, H. B., and Nelson, R. L. (2011). Proteomic analysis of high protein soybean (Glycine max) accessions demonstrates the contribution of novel glycinin subunits. J. Agric. Food Chem. 59, 2432-2439. doi: 10.1021/ jf104330n

Krishnan, H. B., Oehrle, N. W., and Natarajan, S. S. (2009). A rapid and simple procedure for the depletion of abundant storage proteins from legume seeds to advance proteome analysis: a case study using Glycine max. Proteomics 9, 3174-3188. doi: 10.1002/pmic.200800875

Lange, M., Vincze, E., Wieser, H., Schjørring, J. K., and Holm, P. B. (2007). Effect of an antisense $\mathrm{C}$-hordein gene on the storage protein composition in the barley seed. J. Agric. Food Chem. 55, 6074-6081. doi: 10.1021/jf0709505

Lee, J. D., Woolard, M., Sleper, D. A., Smith, J. R., Pantalone, V. R., Nyinyi, C. N., et al. (2009). Environmental effects on oleic acid in soybean seed oil of plant introductions with elevated oleic concentration. Crop Sci. 49, 1762-1768. doi: 10.2135/cropsci2008.11.0663

Lin, Y., Pajak, A., Marsolais, F., McCourt, P., and Riggs, C. D. (2013). Characterization of a cruciferin deficient mutant of Arabidopsis and its utility for overexpression of foreign proteins in plants. PLOS ONE 8:e64980. doi: 10.1371/journal.pone.0064980

Marsolais, F., Pajak, A., Yin, F., Taylor, M., Gabriel, M., Merino, D. M., et al. (2010). Proteomic analysis of common bean seed with storage protein deficiency reveals up-regulation of sulfur-rich proteins and starch and raffinose metabolic enzymes, and down-regulation of the secretory pathway. J. Proteomics 73, 1587-1600. doi: 10.1016/j.jprot.2010.03.013

Matamoros, M. A., Moran, J. F., Iturbe-Ormaetxe, I., Rubio, M. C., and Becana, M. (1999). Glutathione and homoglutathione synthesis in legume root nodules. Plant Physiol. 121, 879-888. doi: 10.1104/pp.121.3.879

Moravec, T., Schmidt, M. A., Herman, E. M., and Woodford-Thomas, T. (2007) Production of Escherichia coli heat labile toxin (LT) B subunit in soybean seed and analysis of its immunogenicity as an oral vaccine. Vaccine 25, 1647-1657. doi: 10.1016/j.vaccine.2006.11.010

Nielsen, N. C. (1996). "Soybean seed composition," in Soybean: Genetics, Molecular Biology and Biotechnology, eds D. P. S. Verma and R. C. Shoemaker (Wallingford: CABI), 127-163.

Nielsen, N. C., Dickinson, C. D., Cho, T. J., Thanh, V. H., Scallon, B. J., Fischer, R. L., et al. (1989). Characterization of the glycinin gene family in soybean. Plant Cell 1, 313-328. doi: 10.1105/tpc.1.3.313

Nielsen, N. C., and Nam, Y. W. (1999). "Soybean globulins," in Seed Proteins, eds P. R. Shewry and R. Casey (Dordrecht: Kluwer Academic Publishers), 285-313. doi: 10.1007/978-94-011-4431-5 13

Odanaka, H., and Kaizuma, N. (1989). Mutants on soybean storage proteins induced with $\gamma$-ray irradiation. Jpn. J. Breed. 39, 430-431.

Ogawa, T., Tayama, E., Kitamura, K., and Kaizuma, N. (1989). Genetic improvement of seed storage protein using three variant alleles of $7 \mathrm{~S}$ globulin subunits in soyabean. (Glycine max L.). Jpn. J. Breed. 39, 137-147. doi: 10.1270/jsbbs1951.39.137

Panthee, D. R., Kwanyuen, P., Sams, C. E., West, D. R., Saxton, A. M., and Pantalone, V. R. (2004). Quantitative trait loci for $\beta$-conglycinin (7S) and glycinin (11S) fractions of soybean storage protein. J. Am. Oil Chem. Soc. 81, 1005-1012. doi: 10.1007/s11746-004-1014-4

Piller, K. J., Clemente, T. E., Jun, S. M., Petty, C. C., Sato, S., Pascual, D. W., et al. (2005). Expression and immunogenicity of an Escherichia coli K99 fimbriae subunit antigen in soybean. Planta 222, 6-18. doi: 10.1007/s00425-0041445-9

Rao, S. S., and Hildebrand, D. (2009). Changes in oil content of transgenic soybeans expressing the yeast SLC1 gene. Lipids 44, 945-951. doi: 10.1007/s11745-0093337-z

Scherer, H. W., Pacyna, S., Spoth, K. R., and Schulz, M. (2008). Low levels of ferredoxin, ATP and leghemoglobin contribute to limited $\mathrm{N}_{2}$ fixation of Peas (Pisum sativum L.) and alfalfa (Medicago sativa L.) under S deficiency conditions. Biol. Fertil. Soils 44, 909-916. doi: 10.1007/s00374-008-0273-7

Schmidt, M. A., Barbazuk, W. B., Sandford, M., May, G., Song, Z., Zhou, W., et al. (2011). Silencing of soybean seed storage proteins results in a rebalanced protein composition preserving seed protein content without major collateral changes in the metabolome and transcriptome. Plant Physiol. 156, 330-345. doi: 10.1104/pp.111.173807

Schmidt, M. A., and Herman, E. M. (2008). Proteome rebalancing in soybean seeds can be exploited to enhance foreign protein accumulation. Plant Biotech. J. 6, 832-842. doi: 10.1111/j.1467-7652.2008.00364.x
Scossa, F., Laudencia-Chingcuanco, D., Anderson, O. D., Vensel, W. H., Lafiandra, D., D'Ovidio, R., et al. (2008). Comparative proteomic and transcriptional profiling of a bread wheat cultivar and its derived transgenic line overexpressing a low molecular weight glutenin subunit gene in the endosperm. Proteomics 8 , 2948-2966. doi: 10.1002/pmic.200700861

Segal, G., Song, R. T., and Messing, J. (2003). A new opaque variant of maize by a single dominant RNA-interference-inducing transgene. Genetics 165, 387-397.

Shewry, P. R. (2000). "Seed proteins," in Seed Technology and its Biological Basis, eds M. Black and J. D. Bewley (Sheffield: Sheffield Academic Press), 42-84.

Shigemitsu, T., Ozaki, S., Saito, Y., Kuroda, M., Morita, S., Satoh, S., et al. (2012). Production of human growth hormone in transgenic rice seeds: co-introduction of RNA interference cassette for suppressing the gene expression of endogenous storage proteins. Plant Cell Rep. 31, 539-549. doi: 10.1007/s00299-0111191-y

Song, S., Hou, W., Godo, I., Wu, C., Yu, Y., Matityahu, I., et al. (2013). Soybean seeds expressing feedback-insensitive cystathionine- $\gamma$-synthase exhibit a higher content of methionine. J. Exp. Bot. 64, 1917-1926. doi: 10.1093/jxb/ert053

Spencer, D., Rerie, W., Randall, P., and Higgins, T. (1990). The regulation of pea seed storage protein genes by sulfur stress. Funct. Plant Biol. 17, 355-363.

Staswick, P., Hermodson, M. A., and Nielsen, N. C. (1984). Identification of the cystines which link the acidic and basic components of the glycinin subunits. J. Biol. Chem. 259, 13431-13435.

Streatfield, S. J. (2007). Approaches to achieve high-level heterologous protein production in plants. Plant Biotech. J. 5, 2-15. doi: 10.1111/j.14677652.2006.00216.x

Tabe, L., Hagan, N., and Higgins, T. J. (2002). Plasticity of seed protein composition in response to nitrogen and sulfur availability. Curr. Opin. Plant Biol. 5, 212-217. doi: 10.1016/S1369-5266(02)00252-2

Tabe, L. M., and Droux, M. (2001). Sulfur assimilation in developing lupin cotyledons could contribute significantly to the accumulation of organic sulfur reserves in the seed. Plant Physiol. 126, 176-187. doi: 10.1104/pp. 126.1.176

Tabe, L. M., and Higgins, T. J. (1998). Engineering plant protein composition for improved nutrition. Trends Plant Sci. 3, 282-286. doi: 10.1016/S13601385(98)01267-9

Tabe, L. M., Wirtz, M., Molvig, L., Droux, M., and Hell, R. (2010). Overexpression of serine acetlytransferase produced large increases in $O$-acetylserine and free cysteine in developing seeds of a grain legume. J. Exp. Bot. 61, 721-733. doi: 10.1093/jxb/erp338

Tada, Y., Utsumi, S., and Takaiwa, F. (2003). Foreign gene products can be enhanced by introduction into low storage protein mutants. Plant Biotech. J. 1, 411-422. doi: 10.1046/j.1467-7652.2003.00038.x

Takahashi, K., Banba, H., Kikuchi, A., Ito, M., and Nakamura, S. (1994). An induced mutant line lacking the $\alpha$-subunit of $\beta$-conglycinin in soybean (Glycine $\max$ (L.) Merrill). Jpn. J. Breed. 44, 65-66. doi: 10.1270/jsbbs 1951.44 .65

Takahashi, M., Uematsu, Y., Kashiwaba, K., Yagasaki, K., Hajika, M., Matsunaga, R., et al. (2003). Accumulation of high levels of free amino acids in soybean seeds through integration of mutations conferring seed protein deficiency. Planta 217 , 577-586. doi: 10.1007/s00425-003-1026-3

Taylor, M., Chapman, R., Beyaert, R., Hernández-Sebastià, C., and Marsolais, F. (2008). Seed storage protein deficiency improves sulfur amino acid content in common bean (Phaseolus vulgaris L.): redirection of sulfur from gamma-glutamyl-S-methyl-cysteine. J. Agric. Food Chem. 56, 5647-5654. doi: $10.1021 /$ jf800787y

Thanh, V. H., and Shibasaki, K. (1978). Major proteins of soybean seeds. subunit structure of $\beta$-conglycinin. J. Agric. Food Chem. 26, 692-695. doi: 10.1021/jf60217a026

Townsend, J. A., and Thomas, L. A. (1994). Factors which influence the Agrobacterium-mediated transformation of soybean. J. Cell Biochem. Supp. 18A, 78-86.

Varin, S., Cliquet, J. B., Personeni, E., Avice, J. C., and Lemauviel-Lavenant, S. (2010). How does sulphur availability modify $\mathrm{N}$ acquisition of white clover (Trifolium repens L.)?A J. Exp. Bot. 61, 225-234. doi: 10.1093/jxb/ erp303

Wesley, S. V., Helliwell, C. A., Smith, N. A., Wang, M., Rouse, D. T., Liu, Q., et al. (2001). Construct design for efficient, effective and high-throughput gene silencing in plants. Plant J. 27, 581-590. doi: 10.1046/j.1365-313X.2001.01105.x 
Yagasaki, K., Kaizuma, N., and Kitamura, K. (1996). Inheritance of glycinin subunits and characterization of glycinin molecules lacking the subunits in soybean (Glycine max (L.) Merr.). Breeding Sci. 46, 11-15.

Zhang, Z., Xing, A., Staswick, P. E., and Clemente, T. (1999). The use of glufosinate as a selective agent in Agrobacterium-mediated transformation of soybean. Plant Cell Tiss. Org. 37, 37-46. doi: 10.1023/A:1006298 622969

Zhao, F. J., Hawkesford, M. J., and McGrath, S. P. (1999a). Sulphur assimilation and effects on yield and quality of wheat. J. Cereal Sci. 30, 1-17. doi: 10.1006/jcrs.1998.0241

Zhao, F. J., Wood, A. P., and McGrath, S. P. (1999b). Effects of sulphur nutrition on growth and nitrogen fixation of pea (Pisum sativum L.). Plant Soil 212, 207-217. doi: 10.1023/A:1004618303445

Zuber, H., Poignavent, G., Le Signor, C., Aimé, D., Vieren, E., Tadla, C., et al. (2013). Legume adaptation to sulfur deficiency revealed by comparing nutrient allocation and seed traits in Medicago truncatula. Plant J. 76, 982-996. doi: $10.1111 /$ tpj. 12350
Conflict of Interest Statement: The authors declare that the research was conducted in the absence of any commercial or financial relationships that could be construed as a potential conflict of interest.

Received: 12 September 2014; accepted: 24 October 2014; published online: 11 November 2014.

Citation: Kim W-S, Jez JM and Krishnan HB (2014) Effects of proteome rebalancing and sulfur nutrition on the accumulation of methionine rich $\delta$-zein in transgenic soybeans. Front. Plant Sci. 5:633. doi: 10.3389/fpls.2014.00633

This article was submitted to Plant Physiology, a section of the journal Frontiers in Plant Science.

Copyright (c) $2014 \mathrm{Kim}$, Jez and Krishnan. This is an open-access article distributed under the terms of the Creative Commons Attribution License (CC BY). The use, distribution or reproduction in other forums is permitted, provided the original author(s) or licensor are credited and that the original publication in this journal is cited, in accordance with accepted academic practice. No use, distribution or reproduction is permitted which does not comply with these terms. 